\title{
The Interface Between WIPO and Paris Convention in Protection IPR
}

\author{
Dr. Nashat Mahmoud Abdalla Jaradat \\ Private Law Department, Law College, Applied Science University, Bahrain \\ Nashat.jaradat@asu.edu.bh
}

\begin{abstract}
This research work aims to establish a link between WIPO and Paris Convention from national and international perspectives. Furthermore, the lack of implementation of legislation at the national level is one of the greatest setbacks in the history of IPR protection. Basically, the value of human rights is largely tested by its implementation. The earlier form of Industrial property underwent a transformation after the Paris Convention to be nomenclature as Intellectual property. IPRs, such as patents, plant variety protection, copyrights, and trademarks, are exclusive monopoly rights over a creation that the society provides to the inventor for a period of time. While such monopoly protection obviously restricts the dissemination of knowledge, it is supposed to be counterbalanced by the incentive that it provides to innovate. Intrinsic, natural, interrelated, indivisible, inalienable, basic, instrumental, and inherent rights are ought to be protected if required, for maintaining peace in the society. Imperialism, colonialism, and inequalities among the states were some reasons of concern for the development of IPR.
\end{abstract}

Keywords: IPR, Industrial, Design, Convention, WIPO,Protection

DOI: $10.7176 / \mathrm{IAGS} / 92-02$

Publication date: December $31^{\text {st }} 2021$

\section{Introduction}

International intellectual property law is a patchwork area of intersecting multilateral and bilateral agreements and their resulting harmonization of national laws. It has become an increasingly important and frequently litigated area, particularly in the patent, copyright, and trademark arenas. In addition, in the past few decades, there have been louder calls for the protection of domain names, databases, software, and traditional knowledge. Many of these cutting-edge intellectual property issues are addressed on an international level through the World Intellectual Property Organization (WIPO). Along with new forms of protection, the trend towards globalization in the trade arena has had a direct effect on the harmonization of national intellectual property laws through the World Trade Organization (WTO) and regional trade organizations. With increased interest in international intellectual property law, there are now numerous high-quality electronic resources that cover various facets of this ever-changing area.

Intellectual property is a concept of recent origin. Different parts of the world having different cultures, traditions and lifestyles have different definitions of human rights as well. Intellectual Property Rights (IPR) is the creation of the human mind. From one perspective, the modern development of international law has been a remarkable success. The general opinion is that violations of international human rights law are not due to the inadequacy of its rules. Rather, they stem from an unwillingness to respect the rules, from insufficient means to enforce them, from uncertainty as to their application in some circumstances, and from a lack of awareness of them on the part of the general public. Due to the weak record of ratification of key human rights treaties many of the problems accord in the image of contemporary human rights law.

IP consists of intangible elements which can be incorporated in, or associated with, goods or services, thereby adding value to them, and IPRs extends to the intellectual component as such, rather than to a single physical object in which that component is embodied. There is a need to focus on the potential of human rights clauses in the World Trade Organization (WTO) being misused as non-tariff barriers to trade. The other fundamental human rights are, in fact, linked to and dependent upon the realization of the human right to development. The right to development is one of the most important human rights, which seeks for the realization of all human rights, i.e. civil, political, economic, social, and cultural ${ }^{1}$.

The Kingdom of Bahrain laws protects intellectual property and is committed to enforcing world-class intellectual property rights protections.

Bahrain launched the "Technology Transfer" program which aims to increase patents in the Kingdom of Bahrain, and to embrace inventions and turn them into projects that contribute to creating jobs for citizens. The program links the academic sector with the industrial and commercial sectors in the Kingdom to contribute to building partnerships between businesses and innovative entrepreneurs.

Bahrain joined the World Intellectual Property Organization (WIPO) Copyright Treaty and the WIPO Performances and Phonograms Treaty and was ranked the 44th country on the World's Economic Forum 20172018 Global Competitiveness Index ${ }^{10}$. 


\section{Statement of Problem}

Intellectual property right (IPR) is the creation of human mind. The relationship between WIPO systems and Paris Convention is complex and calls for a full understanding of the nature and purposes of the intellectual property systems. The glaring and growing in equalities in the distribution of wealth pose a dangerous polarization between the haves and the have-nots. Potential efforts of human beings lead to intellectual outcomes which in turn have a considerable value in economy. Just as raw materials and labour were key resources in the first industrial revolution, intellectual property is a central asset in the information or knowledge-based economy. Right associated with intellectual property which gives protection is referred to as IPR. The main question is how a human rights frame work and the provisions of international law provide tools to address the imbalances in the current IP system and achieve a more development- oriented outcome?

\subsection{Objectives}

1- To develop a stronger link between WIPO and Paris Convention

2- To enhance enforcement mechanisms for effective implementation of Human Rights.

3-To enact more stringent laws for the violation of IPR at international and national levels.

\subsection{Hypothesis}

H1: The Trade-related Aspects of Intellectual Property Rights (TRIPs) agreement obliges all member countries to protect intellectual property rights. It has special implications for human rights when the technology of producing life saving drugs, for instance drugs for AIDS, is controlled by a handful of pharmaceutical companies that can charge prices way above what poor people can afford. The main international human rights treaties of relevance to a rights-based approach to IP policy include the International Covenant on Economic, Social and Cultural Rights and the International Covenant on Civil and Political Rights with about 160 parties each.

H2: These international conventions, treaties and agreements protect IPR by the principle of mutuality, which is again a concept of International law or in other words preemptory norms of general international law. Where an inventor invents a new product in a foreign country, he is allowed to get patent in that foreign country itself provided the state of origin is a member of the agreement and allows similar rights to inventors there. This is nothing but the concept of reciprocity as imbibed from general international law.

H3: It is widely accepted that under human rights States have three types of obligations; the obligation to respect, protect and fulfil rights, and these pertain also to international assistance and cooperation. In order to respect rights States have an obligation to ensure that their policies do not harm the enjoyment of human rights in other countries. Raise awareness of national parliaments about the adverse effects of IP policies of their countries on the enjoyment of human rights. Use existing international human rights rules and mechanisms to raise concerns about the impact of IP rules on the enjoyment of human rights.

\subsection{Design/methodology/approach:}

This research focuses on what has happened in light of the IPR in terms of international Conventions and what legal situations have arisen. The overall situation in relation to WIPO and Paris Convention is discussed in order to analyze the efforts which have been made. and study the situation of the state of affairs in the country with regard to implementing the international rules to protect IPR.

\subsection{Testing of Hypotheses:}

In response to the controversies and differing views concerning how to effectively assist developing countries in terms of improving public health through international trade, the WTO formulated TRIPS in an attempt to balance the interests of the many different stakeholders involved. Some aspire to higher standards of IP protection to promote their technological industries, whilst others would benefit from more flexible IP standards to facilitate transfer of technology and allow them to respond to economic, social and cultural development concerns. The link between intellectual property rules and ethical regulations over genetic research should be institutionalized. Although the debates within the WTO and WIPO will surely be contentious, trade and intellectual property negotiators should embrace rather than resist opening up these organizations to human rights influence. The development of a global economy in which intellectual property plays a central role underscores the need for the human-rights community to claim the rights of the author, creator and inventor, whether an individual, a group, or a community, as a human right. It is equally important for human-rights advocates to protect the moral interests and rights of the community.

\section{Theoretical Background:}

The establishments of the World Trade Organization in 1994 and the international Agreement on Trade-Related Aspects of Intellectual Property Rights in 1995 have strengthened the global character of intellectual property regimes. 
Human rights and intellectual property, two bodies of law that were once strangers, are becoming increasingly intimate. It is something of a mystery why intellectual property and human rights have remained strangers for so long. There is close nexus between IPR \& international law. The general concepts of international law are reflected in the IPR. A study deeper into international law shows the concern towards IPR ${ }^{3}$.

International law envisages that any advancement in science or technology should be shared between countries of the world on mutual basis. This very concept is enshrined in various conventions relating to IPR, which allows exchange of knowledge systems ${ }^{4}$.

Protection of IPR is the concern of every state and the globe as a whole. Protection is granted under national laws relating to IPR as well as under international law5.

International law relating to IPR is found in various statutes like the WTO, TRIPS, and conventions like the Rome Convention, Paris Convention, Madrid Agreement and many others. The national laws of many states have been turned up in accordance with these international laws. Conventions, agreements and treaties have binding force of law particularly because the states are parties to it and are bound by the principle of Pacta Sunt Servand ${ }^{6}$ i.e. to abide by the treaties or conventions in good faith.

The role of International Law Commission (ILC) is noteworthy in the development of law among nations. The progressive development of international law over the years is indent from the works of ILC. But when it comes to IPR, there cannot be an exhaustive law obviously because technology changes from day to day. Most of the crimes relating to IP are today so complex that the existing law cannot cope up with these circumstances. It is my humble suggestion that if the task is entrusted to ILC, it would try to cope up with the changed scenario and prepare more stringent laws for violating IPR ${ }^{7}$.

\section{4. - Literature Review: \\ 4.1 Copyright}

During the earlier stages of negotiations, the WCT was seen as a protocol to the Berne Convention, constituting an update of that agreement since the 1971 Stockholm Conference. However, as an amendment to the Berne Convention required unanimous consent of all parties, the WCT was conceptualized as an additional treaty that supplemented the Berne Convention. The collapse of negotiations around the extension of the Berne Convention during the 1980s saw the shifting of the forum to the GATT, resulting in the TRIPS Agreement. Thus, the nature of any copyright treaty by the World Intellectual Property Organization became considerably narrower, being limited to addressing the challenges posed by digital technologies.

Copyright is a bundle of rights that includes the right to produce, copy, adapt, distribute, publicly perform and display work. Copyright stands for the legal right to prevent others from copying an existing work of an individual. It is such a right which is exclusively given for a definite period of time to the originator (author or creator) of intellectual work such as publication, or an article or a literary work for sale or any other use. ${ }^{2}$

- There are two types of rights under copyright:

economic rights, which allow the rights owner to derive financial reward from the use of their works by others; and moral rights, which protect the non-economic interests of the author.

Most copyright laws state that the rights owner has the economic right to authorize or prevent certain uses in relation to a work or, in some cases, to receive remuneration for the use of their work (such as through collective management). The economic rights owner of a work can prohibit or authorize:

its reproduction in various forms, such as printed publication or sound recording;

its public performance, such as in a play or musical work;

it's recording, for example, in the form of compact discs or DVDs;

it's broadcasting, by radio, cable, or satellite;

its translation into other languages; and

its adaptation, such as a novel into a film screenplay.

Examples of widely recognized moral rights include the right to claim authorship of a work and the right to oppose changes to a work that could harm the creator's reputation ${ }^{8}$.

\subsection{Music piracy}

Music piracy poses a greater threat to the international music industry than at any other time in its history. Traffic in pirate recordings is not only proliferating worldwide but also rapidly diversifying into new technologies and formats.

Commercial pirate recordings today range from the traditional cassette to the manufactured $\mathrm{CD}$ and from the $\mathrm{CD}-\mathrm{R}$ disc replicated in a garage or laboratory to the audio file distributed on the internet. Adding to the threat of commercial piracy is the spread of $\mathrm{CD}$ burning, made possible by advances in digital copying technologies.

The fight against internet piracy requires national and international copyright rules to keep pace with technological developments. The World Intellectual Property Organization (WIPO) 'internet treaties' of 1996 are 
an important tool for bringing copyright into the digital age. These treaties make clear that copyright protects the making available and copying of material over the internet, as well as technologies used to manage copying and transmission.

Music piracy is the copying and distributing of recordings of a piece of music for which the rights owners (composer, recording artist, or copyright-holding record company) did not give consent. In the contemporary legal environment, it is a form of copyright infringement, which may be either a civil wrong or a crime depending on the jurisdiction. The late 20th and early 21 st centuries saw much controversy over the ethics of redistributing media content, how much production and distribution companies in the media were losing, and the very scope of what ought to be considered piracy - and cases involving the piracy of music were among the most frequently discussed in the debate.

Arguments over legality: In face of the growing encroachment on potential sales from internet piracy, industry associations like the Recording Industry Association of America (RIAA) have lobbied for stricter laws and stricter punishment of those breaking copyright law. Record companies have also turned to technological barriers to copying, such as DRM, to some controversy. These organizations have tried to add more controls to the digital copy of the music to prevent consumers from copying the music. For the most part, the industry has come to a consensus that, if not DRM, then some similar measures are necessary for them to continue to make a profit.

Critics of the record companies' strategy have proposed that the attempts to maintain sales rates are impeding the rights of legitimate listeners to use and listen to the music as they wish. According to the internationally established Organisation for Economic Co-operation and Development, "Existing laws and regulations may be too broad and general to deal adequately with the rapid technological developments that facilitate digital piracy, and policymakers may need to consider enacting some specific provisions to deal with these infringements. Such provisions should not unduly impede legitimate digital communications, nor unreasonably impact on the Internet as an effective communications platform, commercial channel, and educational tool."

There have been several means of free access to copyrighted music for the general public including Napster, LimeWire, and Spotify. Napster was a free file sharing software created by college student Shawn Fanning to enable people to share and trade music files in mp3 format. Napster became hugely popular because it made it so easy to share and download music files. However, the heavy metal band Metallica sued the company for copyright infringement. This led to other artists following suit and shutting down Napster's service. Likewise, LimeWire was a free peer-to-peer file-sharing software similar to that of Napster. The software enabled unlimited file sharing between computers and ended being one of the most popular sharing networks around. Like Napster, LimeWire struggled through multiple legal battles and inevitably wound up being shut down. Spotify and other on-demand streaming services are offering a way for consumers to still get their music for free while also contributing to the musician in a small way instead of simply illegally downloading the music, but it also moves customers away from buying hard copies of music or even legally downloading songs which is severely reducing artists' income.

According to the Recording Industry Association of America (RIAA) since Shawn Fanning started the program file-sharing program Napster in 1999 music revenue has gone down 53\% from \$14.6 billion to $\$ 7.0$ billion in 2013. A study done in 2007 by the Institute of Policy Innovation states that music piracy resulted in a loss of 71,060, out of which 23,860 would have been in the recording industry and 44,200 in other unrelated industries 9 .

\subsection{International Patent Law}

The WTO sought to create a practical, balanced framework for patent protection in creating TRIPS. In theory, this notion of balance and fairness should apply to protect the profits of manufacturers in the pharmaceutical industry, as well as provide methods to gain access to critical medications in developing countries. TRIPS generally mandates that inventors and manufacturers receive twenty years of patent protection for their products or processes. The WTO and its member nations have recognized that special circumstances may exist that should excuse countries from performing their obligations and special exceptions have been written into IRPS ${ }^{3}$. In principle, the patent owner has the exclusive right to prevent or stop others from commercially exploiting the patented invention. In other words, patent protection means that the invention cannot be commercially made, used, distributed, imported, or sold by others without the patent owner's consent. Patents are territorial rights. In general, the exclusive rights are only applicable in the country or region in which a patent has been filed and granted, in accordance with the law of that country or region.

-Types of patents

Biological patent - the scope and reach of biological patents vary among jurisdictions and may include biological technology and products, genetically modified organisms, and genetic material. The applicability of patents to substances and processes wholly or partially natural in origin is a subject of debate. 
Business method patent - includes patents on new types of e-commerce; and on methods of doing business in insurance, banking, tax compliance, etc. A business method may be defined as "a method of operating any aspect of an economic enterprise".

Tax patent - discloses and claims a system or method for reducing or deferring taxes ${ }^{13}$.

- Protection Under the Paris Convention

Most industrialized nations have signed the Paris Convention, which provides reciprocal rights related to filing patent applications. An inventor still needs to file a separate application in each country that has signed the Convention, each country will use it from the filing date for the application is registered to take advantage of this protection, an inventor must file their application in the foreign country within a year of filing the Inventors of design patents and must file within six months of the filing.

\subsection{Protection Under the Patent Cooperation Treaty}

The Patent Cooperation Treaty is another international treaty that has been signed by most industrialized nations. It files a PCT application for a reasonable cost within one year of filing an application for a patent. The filing date extends to every member country of the treaty, and the patent search procedure will be simplified. Eventually, the file has a separate application in each country or region where you are seeking protection, but a single international patent search greatly reduces the cost.

It files a foreign patent application six months after filing. patent application, or sooner if you get a PCT license to file the foreign application. Then, you can get permission for a delay of 20 or 30 months before filing a separate application in each PCT country where you want protection ${ }^{11}$.

The costs of preparing and filing a patent application, prosecuting it until grant and maintaining the patent vary from one jurisdiction to another, and may also be dependent upon the type and complexity of the invention, and on the type of patent.

The European Patent Office estimated in 2005 that the average cost of obtaining a European patent (via a Euro-direct application, i.e. not based on a PCT application) and maintaining the patent for a 10-year term was around $€ 32,000$. Since the London Agreement entered into force on May 1, 2008, this estimation is however no longer up-to-date, since fewer translations are required ${ }^{12}$.

\subsection{Industrial Design}

Industrial design is a process of design applied to physical products that are to be manufactured by mass production. It is the creative act of determining and defining a product's form and features, which takes place in advance of the manufacture or production of the product. In contrast, manufacture consists purely of repeated, often automated, replication, while the craft-based design is a process or approach in which the form of the product is determined by the product's creator largely concurrent with the act of its production.

All manufactured products are the result of a design process, but the nature of this process can vary. It can be conducted by an individual or a team, and such a team could include people with varied expertise (e.g. designers, engineers, business experts, etc.). It can emphasize intuitive creativity or calculated scientific decision-making, and often emphasizes a mix of both. It can be influenced by factors as varied as materials, production processes, business strategy, and prevailing social, commercial, or aesthetic attitudes. Industrial design, as applied art, most often focuses on a combination of aesthetics and user-focused considerations, but also often provides solutions for problems of form, function, physical ergonomics, marketing, brand development, sustainability, and sales.

\subsection{Industrial design rights}

Industrial design rights are intellectual property rights that make exclusive the visual design of objects that are not purely utilitarian. A design patent would also be considered under this category. An industrial design consists of the creation of a shape, configuration or composition of pattern or color, or combination of pattern and color in three-dimensional form containing aesthetic value. An industrial design can be a two- or three-dimensional pattern used to produce a product, industrial commodity, or handicraft. Under the Hague Agreement Concerning the International Deposit of Industrial Designs, a WIPO-administered treaty, a procedure for an international registration exists. An applicant can file for a single international deposit with WIPO or with the national office in a country party to the treaty. The design will then be protected in as many member countries of the treaty as desired $^{14}$.

\subsection{Design process}

Although the process of design may be considered 'creative,' many analytical processes also take place. In fact, many industrial designers often use various design methodologies in their creative process. Some of the processes that are commonly used are user research, sketching, comparative product research, model making, prototyping and testing. These processes are best defined by the industrial designers and/or other team members. 
Industrial designers often utilize 3D software, computer-aided industrial design and CAD programs to move from concept to production. They may also build a prototype first and then use industrial CT scanning to test for interior defects and generate a CAD model. From this the manufacturing process may be modified to improve the product. Product characteristics specified by industrial designers may include the overall form of the object, the location of details with respect to one another, colors, texture, form, and aspects concerning the use of the product. Additionally, they may specify aspects concerning the production process, choice of materials and the way the product is presented to the consumer at the point of sale. The inclusion of industrial designers in a product development process may lead to added value by improving usability, lowering production costs, and developing more appealing products ${ }^{15}$.

\section{5- Conclusion and Suggestions:}

1- There is a need for developing proactive, transparent and integrated IPR management regime. Such regime shall be promptly implemented.

2- There is need to exchange information on the latest research findings and development efforts relating to the IPR.

3- Develop new guidelines and recommendations for administering the IPR.

4- Expanding the work of the WIPO to develop the regulations for protection of the international copyright is very much required.

5- There ought to be amendment of or review to the existing Conventions. There is urgent need to frame conventions to make a comprehensive estimation of the hitherto growth of the legal framework and enable appropriate changes along with continuity.

6- WIPO is still in the early phase of its establishment and operation. It is important that member states pay their assessed contributions in full, on time and without conditions to enable its effective functioning.

7- The roots of confrontation should be removed.

8- With the recent technological developments and peripheral changes in the use of the IPR, some of the doctrines of IPR will have to be drastically modified.

* Following strategies can be followed with a view to improve international human rights.

1-:ratification of international human rights instruments;

2- enhancement of enforcement mechanisms;

3- measures for effective national implementation;

4- respect for human rights by parties to the conflict;

5- dissemination of conventions;

6- enactment of penal legislations;

7- translation of treaties into national languages.

\section{References}

1- See WTO report 2008.

2- Supra note 5.

3- D P Mittal ,Indian Patent Law and Procedure, Taxman Allied Services Pvt p 313.

4- P Narayan,(2002), Copyright and Industrial Designs,(Eastern Law House ), also Lione Beantly Brad Sherman,(2003), Intellectual Property Rights, Oxford University Press,p 109

5- Ibid,see 1967 Convention.

6- Duty to fulfill international obligations in the light of good faith, it is a universal norm should be accepted.

7- Malcolm Shaw, International Law, see state responsibility.

8- https://www.wipo.int/copyright/en/

9- Johns, Adrian. (2009). Piracy: The Intellectual Property Wars from Gutenberg to Gates. University of Chicago Press. p354.

10- https://www.bahrain.bh/new/en/intellectualprop en.html

11- Mallor, Jane (5 January 2012). BUSINESS LAW: THE ETHICAL, GLOBAL, AND E-COMMERCE ENVIRONMENT (15th ed.). McGraw-Hill/Irwin. p. 266

12- James W. Cortada, "Rise of the knowledge worker, Volume 8 of Resources for the knowledge-based economy", Knowledge Reader Series, Butterworth-Heinemann, 1998, p. 141

13- Faunce, Thomas (August 6, 2004). "The awful truth about evergreening"P.162.

14- "Oskar Barnack". International Photography Hall of Fame and Museum. Retrieved, P 216, 23 March 2021.

15- Dyson, James (1997). Against the odds: An autobiography. London: Orion Business, P 257. 